\title{
Video games reviewed as framing tool for political actor in petualangan Jokowi games
}

\author{
Wahyu Juliangga \\ Universitas Indonesia, Depok, Indonesia
}

\begin{abstract}
Digitalization created new development in the interactive model used by political actors. One of the models is video games as a propaganda tool for electoral interest. This study tries to elaborate on the role of a video game called "Petualangan Jokowi." This study used Political Campaigning Games (PCG) framework with game analysis as the primary method with textual and user experience approach by the casual gamers. This study showed that the video game "Petualangan Jokowi" on advergames definition based on textual approach is a by-design game for promoting Joko Widodo and another political actor inside the games to casual gamers. This game succeeds in partially framing the political actors' characters who will be the focus inside Petualangan Jokowi. But the casual gamers are distressed to get the political message which is shown by the symbol and the story because of the shortcoming of development in content and functionality. This study also indicates casual gamers do not want to stick outplayed Petualangan Jokowi because there is no incentive for casual gamers to play Petualangan Jokowi for a long time. This factor implies the not effectively framing process because the casual gamers only received partial political messages based on lack of experience played Petualangan Jokowi.
\end{abstract}

Keywords: Video games; framing; political actor; petualangan Jokowi; political campaign games (pcg)

\section{ABSTRAK}

\section{Tinjauan video games sebagai alat framing aktor politik pada game Petualangan Jokowi}

Digitalisasi menciptakan bentuk perkembangan dalam model interaksi yang dilakukan oleh aktor politik. Salah satu bentuk digitalisasi ini adalah penggunaan video games sebagai alat propaganda untuk kepentingan elektoral. Studi ini mencoba untuk melihat tinjauan peranan video games sebagai alat framing yang dilakukan oleh aktor politik dengan objek studi video game Petualangan Jokowi. Studi ini menggunakan kerangka Political Campaign Games (PCG) dengan metode analisis game secara tekstual dan melalui user experience dari Casual Gamers. Hasil studi ini menunjukan bahwa video game Petualangan Jokowi dalam tinjauan advergames secara tekstual merupakan game yang diciptakan untuk promosi Joko Widodo dan karakter aktor politik lain di dalam game kepada casual gamers. Game ini berhasil melakukan penonjolan tekstual terhadap karakter aktor-aktor politik yang menjadi fokus dalam Petualangan Jokowi. Di sisi lain, para casual gamers tidak mampu menangkap pesan yang muncul dari simbol serta cerita. Hal ini dikarenakan kelemahan dalam pengembangan konten dan fungsional game. Studi ini juga menunjukan casual gamers enggan untuk bertahan memainkan Petualangan Jokowi karena tidak adanya insentif, stimulan yang membuat casual gamers dapat bermain Petualangan Jokowi secara berkelanjutan. Faktor tersebut menyebabkan proses framing aktor politik tidak berjalan efektif karena casual gamers hanya memperoleh pesan politik secara parsial akibat dari singkatnya waktu bermain Petualangan Jokowi.

Kata-Kata kunci: Video games; framing; aktor politik; petualangan jokowi; political campaign games (pcg)

Korespondensi: Wahyu Juliangga, S.I.P. Universitas Indonesia. Kampus Depok, Gedung A, Fakultas Ilmu Sosial dan Ilmu Politik Kampus UI, Depok, 16424,.Email: wahyu.juliangga01@ui.ac.id 


\section{INTRODUCTION}

The development of communication medium adopted widely in daily life, especially for the political elite to find an ideal mode to interact with the constituent member (Epstein, 2018). One of the platforms used by the political elite is a computer \& mobile video games. Video games as an alternative medium when the political elite felt the old media ecosystem such as television, newspaper, and radio went to saturation mode (Baltezarevic et al., 2019). The supportive argument says that political parties prioritize the usage of social media also video games ecosystem with different real constructs. Nowadays, many video games created by the developer allied with a political party and political actor to promote political campaigns, especially in the electoral term.

Video games used as a political campaign in the US Context since the Presidential election in 2008. The Republican Party released a video game called tax invaders as a propaganda tool for John McCain Campaign with little impact on his electability (Bogost, 2011). In Democratic Party collaborated with Nintendo to release Super Obama World with Barack Obama as the main actor. After the election, Obama still used video games to put his character in many games, especially in sports genres such as basketball player symbol, to maintain his popularity in younger voters (Bogost, 2011). That pattern was used as an asset in the 2012 Presidential election. In the 2016 Presidential Election, all candidates created mobile video games with the donation feature also the propaganda tool. Mobile Video Games are not only a good framing tool, including negative campaigns such as criticizing and reproaching the opponent's personality. This showed the progress in the functionality of the video games not only to entertain the user and deliver a persuasive message. However, there is some participatory mode with a direct donation also offensive negative framing to the political opponent.

In the Indonesian context, video games used as a political campaign since 2012. Selamatkan Jakarta was the first mobile video game to support Joko Widodo-Basuki Tjahaja Purnama campaign in the 2012 Jakarta Governor election. With the semiotics analysis,
Selamatkan Jakarta tried to promote the new Jakarta with the Jokow-Ahok symbol to destroy corruption, thuggery and solve the waste issue (Poentarie, 2014). This phenomenon continued in the 2014 Presidential election, with JokowiKalla team forming Jokowi Go and Prabowo the Asian Tiger in the Prabowo-Hatta team. Jokowi Go contained a representative program, positive personality framing, interactivity, and social media connectivity.

Meanwhile, Prabowo the Asian Tiger only showed the candidate program and dominant framing to Prabowo (Halim \& Widayatmoko, 2015). This study still focused on video games as campaign methods and program promotion only. The mobile games didn't aim as a participatory maximization mode for mass interactivity mobilization and negative framing from the design and feature inside the game.

The video games perspective moved to negative framing since US Presidential election in 2016. Russian Internet agency produced a game called Hilltendo a few weeks before the election date in November 2016. Hilltendo focused on imposing Hillary Clinton popularity with some negative framing, such as Hillary as Middle East agency with Money-oriented agenda and a person who would plan to change the constitution (Pagliary \& O'Sullivan, 2018). This practice was copied in Brazil with the mobile games Bolsomito 2K18 to persuade the users to play the Bolsonaro character to kill the political opponent and minority group activist (Gomes et al., 2019). These two cases are directly linked with right-wing populism groups (conservative) in Brazil and USA. Meanwhile, in Indonesia's context until 2014, all elite politics contested in election used mobile video games apart from their political ideology.

Video games as a propaganda tool used by political actors for electoral interest, including personal and opponent framing. Framing moved from news object and now apply in video games with textual symbols (Entman, 1993; Griffin et al., 2018). The textual object is described as a positive affirmation from personal character, program promotion until the successful image of the political actor (Lerner, 2014). On the other side, negative framing includes the textual symbols on Video games to destroy the program and opponent character (Boydstun et al., 2019). The latest development about negative framing in Video Games for Indonesia does not include 
that thing because video games are not a priority tool in the latest 2019 Presidential election.

The research object in this study is the video Game Jokowi Adventure (Petualangan Jokowi). Rio Games as developer released Petualangan Jokowi on December 15, 2018. Rio Games is a game developer who has created seven mobile games on the Android ecosystem in many genres such as arcade, adventure, racing, and puzzling. Petualangan Jokowi is an arcade genre game focusing on gamers above 12 years old.

Petualangan Jokowi has interesting to know more because it is different from many previous studies in relation between mobile video games and electoral political campaigns by the political actor. Petualangan Jokowi develops by a mobile games developer outside the political ecosystem, and the developer used Joko Widodo as the main hero. From the timing context, Petualangan Jokowi, created by the developer still far from the political agenda in the 2024 general election. Not only Joko Widodo, there are another character such as Prabowo Subianto, Basuki Tjahaja Purnama (Ahok) and Grace Natalie.

However, Petualangan Jokowi chooses the arcade genre and has the same design as Bolsomito 2K18. From the gameplay, Petualangan Jokowi and Bolsomito 2K18 aim to kill political opponents from Joko Widodo and Jair Bolsonaro. These games have an abstract representation because the function and design are customized with the casual gamers as the leading player (Bogost, 2007). The casual gamers only play video games for having fun and not wasting time so long in one game (Fernández-Vara, 2014). This research will learn more about Petualangan Jokowi as a video game used for the Joko Widodo and another political actor framing from the casual gamers' textual and user interaction process.

This study uses Political Campaigning Games (PCG) model as the main theoretical framework from Michael Bossetta (Bossetta, 2019). PCG is apart from advergames with the primary goal to promote partisan political position in the electoral context. Advergames is a one of games brand which design to promote some product. Advergames aim to send a strong message to users about the brand and the implicit message inside the text (Quilliam et al., 2011; Terlutter \& Capella, 2013). Based on that definition, PCG consists of three main interrelated elements, namely function, content, and context. (Bossetta, 2019).

PCG functions as political ads for candidates or political parties to collect public sympathy and gain popularity. The primary work mechanism started with inserting a good textual message on the game's design, plot, or characterization (Bossetta, 2019). Advergames context exists in the PCG as a part of the advertisement process from the video games. PCG as advergames caused the design of games entirely with the advertisement content implicit or explicit and focused user goes to casual gamers (Fernández-Vara, 2014). The gaming design process is a simple game to get many users and coverage widely. Political campaign message dominant in the design also gameplay, so it would be easy sending to the public.

PCG content is a part of political position from ads or campaigns inside the games. Games content in the biased and partisan as advergames function in political terms to promote political topics and framing agenda. PCG is widely open to infiltration with partisan conflict rather than issue framing. Conflict framing is a base for visual design, sound, and animation for the main content (Bossetta, 2019). Framing conflict would appear in abstract visual with multiple meaning contexts (Bogost, 2007).

Lastly, functional and content context is influenced by the latest political situation. Specifically, the PCG context related to the political campaign process to create multiple actor conflict as political communication innovation. This context would emphasize conflict framing. Adaptation by the developer with the actual situation should to done. Real situations directly influenced the content form and framing, especially in the meaning-created process and conflict applied in the visual and audio content of the games. Functionality would impact the simple design and gameplay related to the political context and moment (Bossetta, 2019).

\section{RESEARCH METHODS}

This study uses the constructivism paradigm. The main problem would be researched due to social reality and the correctness from social reality having the 
Table 1 Informants List

\begin{tabular}{cccc}
\hline No. & Name & Age/Profession & Progress \\
\hline 1 & Nana & 17 Years/Student & Level 2 \\
2 & Nopi & 30 Years/Consultant & Level 3 \\
3 & Ngurah & 24 Years/Student & Finish \\
4 & Cahya & 24 Years/Civil Servant & Level 2 \\
5 & MA Gamers & Gamer Reviewer & - \\
6 & Friday Channel 33 & Gamer Reviewer & - \\
\hline
\end{tabular}

Source: Research Findings, 2021

relative characteristic. The researcher who used this paradigm learned some constructed reality by the individual and implicated it to daily life (Patton, 2014). The researcher used this paradigm because of the variety of individual experiences and perceptions played by the Video Games "Petualangan Jokowi." This implicated to research approach model and analysis methods reaching the analysis of the game with the textual and user interaction function.

Analysis Game is the primary method with the qualitative approach in this study. (FernándezVara, 2014). There are two analytical areas: a game overview and mechanical detail games. These two areas combine with two Political Campaign Games elements. It started with the game overview and the main political message as textual content. Then move to mechanical details about how the message is constructed in the textual, storyline, and gameplay. The analysis would focus on formal elements and game overview (Fernández-Vara, 2014).

To collect data, the researcher used interview methods to collect primary data from some casual gamers. The researcher used the interview to know more about the experience and perception after the informant played the games. Also, to collect data about the framing from the political actors involved in the game. Besides interviews for the primary data, the researcher used textual methods with observation to game design, storyline, character, and graphics using screen capture featuretextual analysis combined with the interview data in the analysis level.

The interview process was held on June 24-25 with four informants and two gamers reviewers with the snowball sampling method. The informant comes from one of the reviewers Petualangan Jokowi in Playstore, and the researcher finds another informant also reviewer from the suggestion on the previous informant. All informants and reviewers played all the characters and some level at that game before the research was held. The primary data from casual gamers were used to see how the experience and understanding of the message also the interactivity of the informant, in table 1 .

A semi-structured model held the interview deal. Before the interview started, the researcher asked the informant to play Petualangan Jokowi Games again at least twice. The purpose to memory refreshment if the informant in a long time is not played Petualangan Jokowi or similar games in the arcade genre. All of the informants are ready to be recorded, and the interview transcript is the process by the coding step - the primary data analysis with the Political Campaigning Games framework.

\section{RESULTS AND DISCUSSION}

Content creation aspect determined by Political Campaigning Games framework and game analysis focusing on storyline, goals also the actual message which created framing for political campaign. Based on Petualangan Jokowi in arcade genre with full action of conflict, fight between hero and villain, the hero has a limited soul with the blood symbol. This pattern adopts the old arcade popular game such as Mortal Kombat and Tekken. Joko Widodo is 


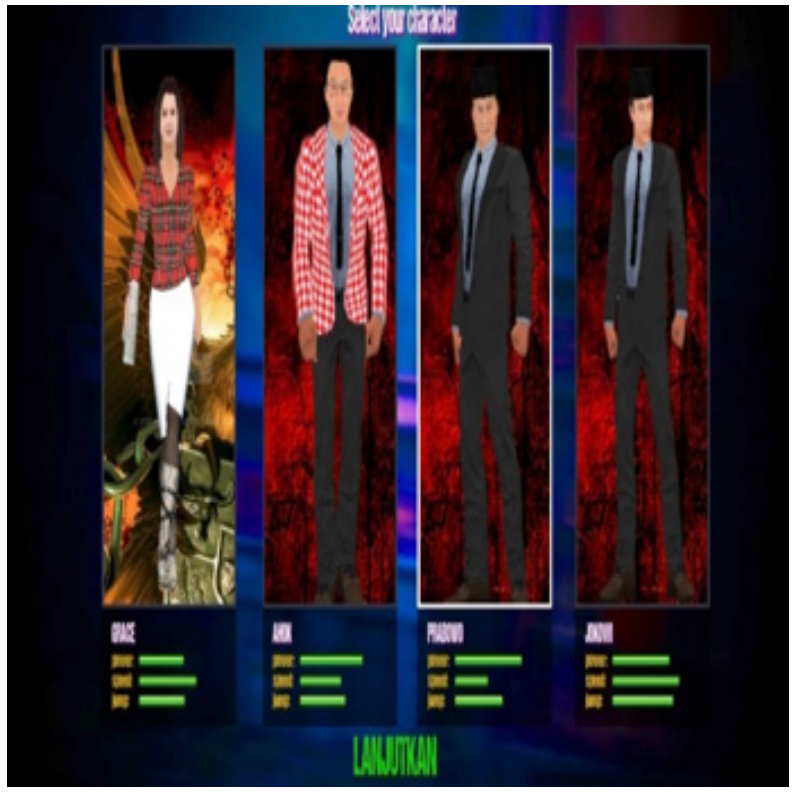

Source: Game Petualangan Jokowi, 2021

Picture 1 Home screen of the Petualangan Jokowi Games

the strongest hero with the prevalent ability of speed, strength, jumping, stance specialization, and punch. Jokowi character is easy to use for combo feature (combine punch and kick in one movement). Another character below has a variety ability and characteristics, in figure 1.

Another three characters in reality at the same political circle as Jokowi. Prabowo, as a ministry of defense and his political party called Gerindra coalition with Jokowi Party (PDIP). Ahok was the former teammate when Jokowi became Jakarta governor in 2012-2014. Grace Natalie is a Partai Solidaritas Indonesia (PSI) leader in the Jokowi administration coalition. Jokowi and Prabowo's characters describe clothing using black suits, ties, and caps. As a textual analysis, the same clothing means they are teammates in Jokowi cabinet administration, but Jokowi has better capability than Prabowo because he is a President; meanwhile, Prabowo is just a minister. The developer created a different symbol for Ahok and Grace with the casual suites because they are not directly on the cabinet. Ahok used a red plaid shirt as a reminder Ahok used that on Jakarta electoral campaign in 2012 and 2017 (Rosida, 2017).

Grace's character looks attractive in this game. Grace is not a suitable character rather than other characters based on the perception of one of the informants below.
"The most important thing in-hero character, for framing agenda, is very explicit the person at the Jokowi circle. Maybe okay for Ahok and Prabowo because in the same coalition with Jokowi, I am confused with Grace because she is not competent rather than another character. Grace is not suitable with another political actor. If the character is based on the political party leader, why not Megawati from PDIP or Airlangga from Golkar." (Nopi, 24 Juni 2021)

On the other side, Grace is the only one woman representative in this game and brings a long hammer as a weapon.

"I Choose Grace, her character usually bring a long hammer. Only her bring a weapon" (Firdan Channel 33, 2020)

"I Choose Grace, previously use Prabowo. But I do not know who she is. I choose because she is a woman." (Nana, 24 Juni 2021)

In PCG analysis, the representative from all actors is a part of the introduction to the casual gamers. (Bossetta, 2019). Because Petualangan Jokowi includes advergames, this game was developed as an ads tool for a political actor. Grace Natalie is an excellent example because she is not in the same position as another character, especially Jokowi and maybe another experienced political actor like Megawati or Airlangga Hartarto. In terms of framing, focusing on one aspect is a part to bolder the story or character (Griffin et al., 2018). Grace as an emphasized actor by the developer introduced to casual gamers. The developer has the main role of choosing which character to focus on with the implication thatthat users want to know more about the character. However, in Petualangan Jokowi, so far, the framing of the in-hero character is not enough to closer between the real-life hero and casual gamers perception.

"After I see Grace Character, I just want to know and find her profile in Wikipedia. I know Grace as a PSI leader and former journalist. But after that is enough to find her profile." (Nana, 24 Juni 2021)

On the storyline aspect, after the users choose one character, the next steps to follow 
the mission kill the opponent from the main character. At least there are eight kinds of an opponent with the identity such as 1). Pejabat Gak Guna (Useless servant), 2). Pejabat Makan Gaji Buta, 3). Kriminal (crime), 4). Koruptor (corruptor), 5). Nyinyirer, 6). Fitnaher, 7). Kartel (cartel) dan 8). Teroris (terrorist). This identity looks interesting in corruptor and cartel in textual context. Jokowi fights against the corruptor, but in reality, the Jokowi administration is doing an anti-political movement to weaken the KPK (Corruption Eradication Commission) works and function (Fariz, 2019). In the cartel context, the Jokowi administration is power-sharing between him and all the parties in the coalition cabinet. (Slater, 2018). This would impact the storyline not actual with the real political context and seems inconsistent with the main political message inside the game.

The opponent character identity looks interesting and slightly satirical, but their physical graphics are monotone. There are only four physical characteristics: a man with a vest with a grenade in his hand, a man with bald hair with a black suit, a man with a suit and a baseball stick, and a man with shaggy hair. The four physical types can play many roles, such as a man with a grenade in a cartel, the terrorist also father, a man with bald hair as a useless servant, and many more. There are many inconsistent physical characters on every level. It shows the developer is not ready to develop character seriously, and the users felt that Petualangan Jokowi is "not ready yet to launch."

"The opponent based on the design is so generic, whereas the character's name is so interesting. I do not know where is the corruptor, fitnaher, useless servant. The form of the character is all the same. Suppose they want to send a political message. I see it is just as troll game." (Cahya, 25 Juni 2021).

Petualangan Jokowi inside the arcade genre adopts the intensive fighting on the design. One main hero would fight against all opponents on the same level. This design will create conflict framing (Bossetta, 2019). To make a perfect conflict framing, the opponent design as the main story should to perfectly designed. However, all the opponent characters and identities created tend to be simple. There are no significant issues that matter, and "the
King" does not appear as the grand opponent, which the arcade genre always has a prominent opponent. If we see the opponent's storyline, we do not know who they are, their reason, and why we should fight against them. Users only know how to fight until the opponent dies as the central conflict, and some statements from the users confirm this.

"I do not see the satire. The storyline does not include the main character to promote politics. For example, Jokowi did not describe who he is; the background story and goal are blurred. His opponent is very unclear. I do not know the reason what they are doing. So, it is only fighting, survival and then the end"' (Cahya, 25 Juni 2021).

"After the play, I think will meet the last King, but not. It is not good for the game and enough to play again." (MA Gamers, 2020).

Personal representation and motive inside the game are sometimes abstract and hard to understand (Bogost, 2007). The basic of the campaign process with clear goals is to make the symbol inside the game easy to understand by the users (Malabar, 2020; Littlejohn et al., 2012). However, the problem inside Petualangan Jokowi comes from not having a clear content structure, especially in the storyline. This caused some players not to catch the entire message from the framing inside the storyline. The background from all characters did not clearly explain their goal to kill the opponent character. Conflict framing between Jokowi and friends and the opponent is not explained clearly, so the main message about Jokowi as the main hero is not delivered. Location background as a part of the story does not support the fights of Jokowi and friends against their opponent with only three templates (a palace, inside the palace, and a bridge) for the location background.

"The background location of the battle is very problematic because it is just a complement factor. For example, the opponent is a corruptor, and the location should be an office or terrorism with the background such as forest where Jokowi coming and hunting the terrorist. Jokowi facing corruptor and terrorist on the same frame is unrealistic." (Nopi, 24 Juni 2021). 
Even the storyline, character, and design as the essential tool for framing are not built well, but the informant could see the symbolic character. Jokowi and their friend's character is described as good person, and they will kill a criminal person and disturb national stability. All of 8 , the opponent character described as murder, criminal, corruptor, etc., is evil in reallife political conditions. They often appear in the media, so the opponent is the popular bad character. Good and bad characterization is the main message seen by some informant statements below.

"The symbolic sign from the all character (Jokowi, Prabowo, Ahok, Grace) to become a good people to fight against crime and murder. The evil symbol such as corruptor, terrorist, useless servant, etc., exist in the real world" (Ngurah, 25 Juni 2021).

\section{"All of the characters are having good muscular, so it's basically they are having power and strong" (Nana, 24 Juni 2021).}

The development of criminal character from the real Jokowi and friends political opponent with some back sound from the real political moment. In the fighting action, when the hero succeeds in hitting and smake the opponent until they fall, there is a back sound, "bangsat Kau," sounded by the opponent. That's back sound came from Imam Supriadi voice (Civil Servant in Badan Pemeriksa Keuangan); at one moment, he challenged Ahok when he was still as the Jakarta Governor. (Tempo, 2016). Imam Supriadi voice "bangsat Kau" was published on his Youtube account. This detail supported a symbolic bad person character to vis-a-vis against good personality directly. However, this detail only came from one informant who knows the source of the voice coming from an antiAhok supporter in the online media. This shows the framing could directly spread if the object has knowledge about the real information.

Functional aspects as a formal element in the game analysis consist of some aspects to support game visualization. Some of the aspects such as the rules, their relation to the real world, level difficulty, game dynamics, and gameplay (Fernandez-Vara, 2015). This aspect influenced how the users played the game and built the interactivity also proximity between users, and some messages constructed in the game.
Petualangan Jokowi was created for casual gamers, so the feature adapted to the easy play a character and having fun orientation (Bogost, 2011; Bossetta, 2019; Fernández-Vara, 2014).

The first thing relates to gameplay rules which inside the Petualangan Jokowi, there are no specific details about what casual gamers should do and prohibit. On the opening stage, there are no clues about how the gameplay works, so casual gamers should find out how to play video games similar to the arcade genre. There is no tutorial. The players freely to killed sporadically without the limitation in times and the opponent condition. There is only blood feature to know how many opponents and myself soul to win every level of play.

"For a game, there is no attention to making it fun. It doesn't include a tutorial. When we're starting to play, there's no guideline on what we should do. It is just a knob which we should push, and we don't know the function. For example, we know the function of blade kknob after we play in several minutes" (Cahya, 25 Juni 2021).

Because there are no started rules, Petualangan Jokowi looks like a brutal game. Brutality supported the conflict framing in the visual. These games only focused on aggressive fightings. The setting of the opponent looks like a gangster fight with so many opponent characters and only one main hero. So Joko Widodo as the main hero, should to killed all the opponents at least 15-20 characters on one level. Because there is no rule in the fighting action, so the casual gamer can do anything to kill with some features and guns inside the games. Naturally, in the arcade genre, there are no specific rules in fighting action, so Petualangan Jokowi developed with the original gameplay in the arcade genre.

Another aspect related to gameplay design. This is the crucial thing that will produce some user played experience, level of difficulty, and in the last, there are some good reasons and feedback for the casual gamers to maintain to play (Reiners \& Wood, 2015). Because Petualangan Jokowi launched in the smartphone and android ecosystem, so the touchscreen area is used as controlling play. The touchscreen area consists of some virtual knob to create a side-scrolling feature, punch and jab, jumping, kicking, etc. One of the good aspects inside 


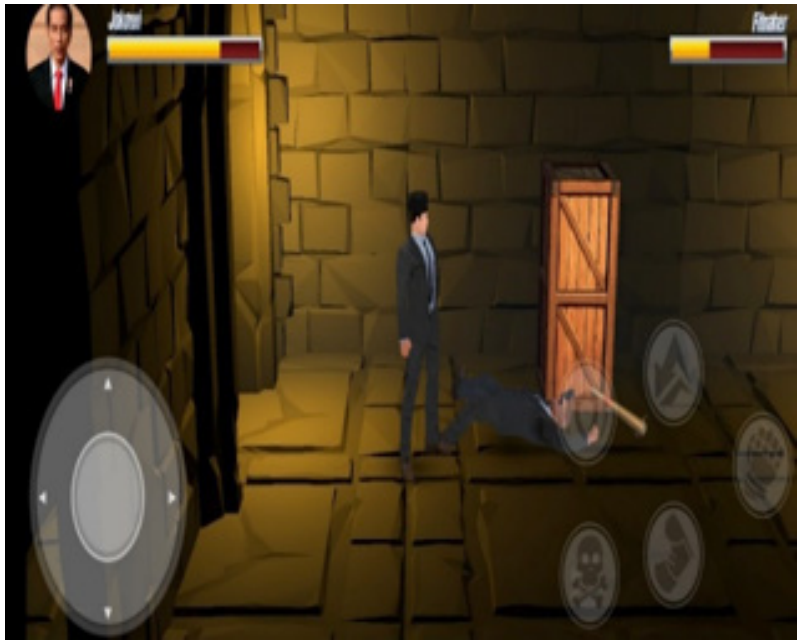

Source: Petualangan Jokowi, 2021

Picture 2 Gameplay Petualangan Jokowi

Petualangan Jokowi, they can maximize the touchscreen area where the left hand is used for side-scrolling and right hand to execution.

There is a positive review from the casual gamers who were satisfied with the gameplay. However, some good gameplay didn't affect interactivity when the political actor fight was directed by the casual gamers: gameplay and lack of the storyline related to each other.

"We can side (turning left, right, up, down) scrolling with the cool graphics" (MA Gamers, 2020).

"The dimension of the game not quite enough, slightly hybrid because we can turn to every direction, but it's rigid." (Cahya, 25 Juni 2021).

Also, Petualangan Jokowi has some weaknesses in the knob functionality. Especially there are delay and bug processes which impact to political actor movement so slow and not smooth enough. Side-scrolling features are a little bit rigid, so the visuality of political actors becomes not flexible when they're fighting. This implies seriously for users convenience, and the relation between users and characters started to weaken.

The next aspect relates to the level of difficulty and game dynamics as an important aspect to see the relation between character and casual gamers also the satisfaction factor. Petualangan Jokowi has five levels such as bencong (level 1), bocah (level 2), normal (level 3), gamer (level 4), and Einstein (level 5). This level naming looks so unique in textual context because these games give a direct message if the player played in the lower level will be called an amateur or beginner level. Otherwise, in the higher level looks expert, professional and clever such as Einstein. These consequences to the gameplay with various difficulties in every level.

"In the beginning, I played at Einstein level, but it's hard. So I'm going down to the bencong level, which is easy. Some levels try to adapt to the capability of the player. But I'm curious to play again in Einstein level because it's hard to fight against the opponent in every gameplay" (Ngurah, 25 Juni 2021).

The difference of the level implies the received message, which is different between the player. At the Einstein level, some players felt so difficult to play and give up, and in the lower level that it was too easy, so they've decided enough to play again. There would be no incentive or reward for the player if they were doing the best job to play in all levels or one level. So the player felt bored and went to another arcade game. Some informants consent about the reward for play in the long term, so the framing process is unsuccessful if there are no loyal player - another informant consent about the development of the gameplay and character. If there are only four characters, it didn't look interesting enough to play in the long term.

"There's no one incentive to stay longer in this game. There are no reward. Another alternative game with better storyline very vast." (Cahya, 25 Juni 2021).

PCG frameworks put the advergames as the part of the game with advertisement message, which in the Petualangan Jokowi, there is a political message in the form of conflict framing (Bossetta, 2019; Terlutter \& Capella, 2013). Petualangan Jokowi from the basic design using political actors behind the Joko Widodo and Ma'ruf Amin administration as a hero. Petualangan Jokowi looks like a partisan game even though it was developed by a private developer. This partisan position is understandable by the casual gamers who know about the Indonesian political condition, such 
as Jokowi, Prabowo, Ahok, and Grace on the same circle in the cabinet right now.

Event casual gamers know Petualangan Jokowi as partisan or advertising games for Joko Widodo and friends, but the conflict framing as the main message in the PCG framework is hard to understand by the player. The representatives of a political actor only as a good person against the bad or crime person. But the background why Jokowi etc. considered a good person, why they're fighting, and the reason for the opponent naming is not explained well. This impact for the player to find out more and influenced to the unclear conflict framing, relation to character, storyline, and the incentive to play again in the long term.

For the electoral campaign interest, game development orientation goes to casual gamers. Casual gamers have characteristics such as they're no problem with the visual, don't have any knowledge about the textual background of the game, and playing for pleasure only, and winning for some opportunity (Eklund, 2020; Juul, 2010). PCG defines casual gamers as playing the simple game so easy to spread the political message Politik (Bossetta, 2019; Eklund, 2020). Some of these definitions should to reviewed because, in Petualangan Jokowi, casual gamers have some expectations about the game, not only about the fighting scene. The expectation came from another arcade genre game such as Mortal Kombat with the high feature, good storyline, easy to follow, and implies the connection between fighter characters and children. This caused imitation from the fighting scene by the children who expose so much from Mortal Kombat (Milani et al., 2015). If Petualangan Jokowi has a goal to create an actor image, it should build close relations and the highest frequency to play the games. Developer should upgrade their capability and feature on the game for perfect campaign and framing.

The incentive to play will impact the framing process. From the research, some players will not continue to play again for several reasons, especially the lack of perfect features, storyline, and reward. Based on the PCG context, it would be a dilemma because the main orientation of PCG goes to casual gamers, but they only play in the short term. Is it enough to create a comprehensive perspective from the framing process inside the textual form of the game? So far, this is the main homework for the developer and political actor to seriously focus on the storyline and reward for successfully framing the process. Good storyline, good features, some reward and various of character also difficulty variance should do first before putting the symbol as a framing process. Incentives are based on interactive experience and make it challenging for users to play again until the limit (Reiners \& Wood, 2015).

This study must see more from the specific character of the user, especially in a younger person as the first or second voter in the election. The framing aspect so interrelated with the experience of play (time and interactivity), so the player will enjoy playing Petualangan Jokowi in the long run. The framing aspect will longer exist for the casual gamers if the developer success in making the loyalty from experience play Petualangan Jokowi. Without that, the framing only goes to partial, or there are no information that matters for the casual gamers.

\section{CONCLUSION}

Based on the textual context and user experience by casual gamers, Petualangan Jokowi as advergames should to given detail aspect especially in character development and storyline. Storyline matters for the framing process because the storyline would create a plot for the user to gain political message easily. So far, casual gamers difficult to knowing the main message explicit and implicit. They are only know the characterization, but it's hard to know more another message such as background conflict with the fighting storyline as a symbol between Political actor action and their opponent. For the framing aspect, Petualangan Jokowi only develop the partial element of political actor personality. The developer didn't build interactivity aspect between the political actor character and the casual gamers. Users only know the identity of the character in real life without knowing more about their deep personality relate to the users.

The development of Petualangan Jokowi as one of the mobilevideo games has a good prospect for alternative political campaign. Petualangan Jokowi would be a reference for casual gamers 
to know more about the real personality of the political elite. But the developer should give an attention to the advergames construction with the characteristic short term played. Incentive matter to maintain casual gamers quantity with the development from the story, character, and reward. Petualangan Jokowi should understand they're in the free market mechanism and compete against another mobile video games in playstore ecosystem. So, Petualangan Jokowi in the future develop the incentive system in design, level of play, story, diversity of the character in every update software. This point would create more interactivity between Petualangan Jokowi and casual gamers as the voters on the next election. With dynamic interactivity and the development of the game, the developer can identify which framing of the political message should to develop related to the real political condition.

This study gives a recommendation to see the impact of the games on a specific group of age users to know about the effectiveness of the framing aspect. From this study, so far the informant in general age can catch some conflict framing information but they're only to consume the information without to know more about the message or build the connectivity to the games and political actor. Mobile video games users in Indonesia will face 75,6 million users in 2025. This huge amount of users as an opportunity to build another advergames not only Petualangan Jokowi to spread political campaign message. Prospect advergames for political campaign widely open and popular, if the developer and some political actor develop these seriously in storyline and interactivity between the character and the casual gamers. Petualangan Jokowi as one of example not perfectly advergames especially in blurred conflict framing but it still can develop seriously for the political campaign.

\section{REFERENCES}

Baltezarevic, R., Baltezarevic, B., Baltezarevic, V., Kwiatek, P., \& Baltezarevic, I. (2019). Political marketing in digital games: 'game over' for traditional political marketing methods. 2(January 2020), 28-47.

Ben Epstein.(2018). The only constant is change: technology, political communication, and innovation over time. https://doi. org/10.1093/oso/9780190698980.001.0001

Bogost, I. (2007). Persuasive games: the expressive power of videogames. MIT Press.

Bogost, I. (2011). How to do Things with videogames. University of Minnesota Press.

Bossetta, M. (2019). Political campaigning games : digital campaigning with Computer games in European National Elections. International Journal of Communication, 13, 3422-3443.

Boydstun, A. E., Ledgerwood, A., \& Sparks, J. (2019). A negativity bias in reframing shapes political preferences even in partisan contexts. Social Psychological and Personality Science, 10(1), 53-61. https:// doi.org/10.1177/1948550617733520

Eklund, L. (2020). Who are the casual gamers? March 2016.

Entman, R. M. (1993). Framing: toward clarification of a fractured paradigm. Journal of Communication, 43(4), 51-58. https://doi.org/10.1111/j.1460-2466.1993. tb01304.x

Fariz, D. (2019). Pemerintahan Joko Widodo dan serangan politik terhadap KPK. Jurnal Antikorupsi Integritas, 05(2), 1933. https://doi.org/10.32697/integritas. v5i2.468

Fernández-Vara， C. (2014). Introduction to game analysis. introduction to game analysis, 1-274. https://doi. org/10.4324/9780203794777

Gomes, L. G., Alves, T. B., Thorstensen, C., \& Soares, I. A. (2019). The 2018 Brazilian elections and the digital world: A case study about the digital game bolsomito $2 \mathrm{k} 18$. Vibrant Virtual Brazilian Anthropology, 16, 1-23. https://doi.org/10.1590/180943412019v16a211

Griffin, E., Ledbetter, A., \& Sparks, G. G. (2018). A first look at communication theory, 10th Edition. In McGraw-Hill. http://www. amazon.com/First-Look-CommunicationTheory/dp/0072291532

Halim, J., \& Widayatmoko, D. (2015). Representasi kampanye politik dalam game (analisis semiotik dalam game Jokowi Go! Dan Game Prabowo The Asian Tiger). 
Jurnal Komunikasi, 7(1), 98-107. https:// journal.untar.ac.id/index.php/komunikasi/ article/view/10

Juul, J. (2010). A casual revolution: reinventing video games and their players. MIT Press.

Lerner, J. (2014). Making democracy fun: how game design can empower citizens and transform politics. MIT Press.

Malabar, F. (2020). Persuasive language in political campaign. 1(October), 76-88.

Milani, L., Camisasca, E., Caravita, S. C. S., Ionio, C., Miragoli, S., \& Di Blasio, P. (2015). Violent video games and children's aggressive behaviors: An Italian study. SAGE Open, 5(3). https://doi. org/10.1177/2158244015599428

Patton, M. Q. (2014). Qualitative Research \& evaluation methods: integrating theory and practice (4th ed.). SAGE Publications Ltd.

Poentarie, E. (2014). Game online "selamatkan Jakarta": analisis semiotika pesan politik kandidat gubernur DKI Jakarta JokowiAhok. JURNAL IPTEKKOM: Jurnal Ilmu Pengetahuan \& Teknologi Informasi, 16(1), 55. https://doi.org/10.33164/ iptekkom.16.1.2014.55-68

Quilliam, E. T., Lee, M., Cole, R. T., \& Kim, M. (2011). The impetus for (and limited power of) business self-regulation: the example of advergames. Journal of Consumer Affairs, 45(2), 224-247. https://doi.org/10.1111/ j.1745-6606.2011.01201.x

Reiners, T., \& Wood, L. C. (2015). Gamification in education and business. Gamification in Education and Business, October, 1-710. https://doi.org/10.1007/978-3-319-102085

Rosida, R. F. (n.d.). Trend kotak-kotak dalam pilkada. $78-88$.

Slater, D. (2018). Party cartelization, indonesianstyle: presidential power-sharing and the contingency of democratic opposition. Journal of East Asian Studies, 18(1), 2346. https://doi.org/10.1017/jea.2017.26

Stephen W. Littlejohn, Foss, K.A., \& Oetzel, J. G. (2012). Theories of human communication eleventh edition. In Waveland Press, Inc. (Vol. 53, Issue 95). https://doi.org/10.1017/ CBO9781107415324.004

Terlutter, R., \& Capella, M. L. (2013). The gamification of advertising: Analysis and research directions of in-game advertising, advergames, and advertising in social network games. Journal of Advertising, 42(2-3), 95-112. https://doi.org/10.1080/0 0913367.2013 .774610 